\title{
Vliv akademického optimismu na výsledky žáků středních škol
}

\author{
Jana Straková, Jaroslava Simonová, Petr Soukup \\ Univerzita Karlova, Pedagogická fakulta
}

\begin{abstract}
Abstrakt: Řada výzkumů ukázala vliv postojů učitelů na výsledky žáků. Jedním z konceptů, prostřednictvím kterého mohou být postoje učitelů operacionalizovány, je akademický optimismus. Zahrnuje vnímání vlastní účinnosti, důvěru $v$ žáky a jejich rodiče a důraz na vzdělávací výsledky žáků. Vliv akademického optimismu na vzdělávací výsledky žáků byl u nás prokázán na nižším sekundárním stupni vzdělávání. Tato studie zkoumá jeho uplatnění na úrovni vyššího sekundárního stupně. Výzkum odpovídá na otázku, zda akademický optimismus učitelů ovlivňuje vzdělávací výsledky $v$ matematice a ve čtenářské gramotnosti při zohlednění počátečních znalostí, socioekonomického statusu, složení žáků školy a typu studia (gymnaziální versus odborné). Analýza je provedena pomocí víceúrovňového strukturního modelování v programu Mplus na datech získaných v letech 2016 a 2018 od 2320 žáků ze 117 tříd prvních a třetích ročníků gymnázií, středního odborného studia s maturitou a středního odborného studia bez maturity a od 795 učitelů všech typů středních škol. Analýza ukázala, že postoje učitelů se $v$ jednotlivých středoškolských programech liší. Jejich vliv na výsledky žáků se však na střední škole nepodařilo prokázat.
\end{abstract}

Kličová slova: akademický optimismus, vzdělávací výsledky žáků, střední škola, longitudinální výzkum, víceúrovňové strukturní modelování

\section{The Impact of Academic Optimism on Achievement of Upper Secondary School Students}

Abstract: A number of studies have shown the impact of teachers' attitudes on student achievement. One of the concepts through which teachers' attitudes can be operationalized is academic optimism. It includes perceptions of self-efficacy, trust in students and their parents, and an emphasis on academic outcomes. The influence of academic optimism on student achievement was demonstrated in the Czech Republic in lower secondary education. This study examines its application at the upper secondary level. The research seeks answer to the question of whether teachers' academic optimism influences educational outcomes in mathematics and reading literacy, taking into account prior achievement, socioeconomic status, school composition and type of study (grammar vs. vocational). The analysis using multilevel structural equation modelling in the Mplus program was performed on data collected in 2016 and 2018 from 2320 students in the first and third years of grammar schools, and secondary technical and apprenticeship schools from 117 classes in 66 secondary schools and from 795 upper secondary teachers. Findings revealed that teachers' attitudes differ between secondary school types. However, their influence on student outcomes could not be proven at the upper secondary school level.

Keywords: academic optimism, student achievement, upper secondary education, longitudinal study, multilevel structural equation modelling 
74 Výzkumníci v oblasti vzdělávání se dlouhodobě zaměřují na hledání faktorů, které mají vliv na výsledky žáků. Významný průlom v tomto úsilí způsobila tzv. Colemanova studie (Coleman et al., 1966), která přinesla doklady o tom, že výsledky žáků lze vysvětlit ve větší míře pưsobením jejich socioekonomického zázemí než vlivy školního vzdělávání. Řada vědců se pak v návaznosti na Colemanovy výsledky snažila ukázat, že na škole přece jenom záleží a že přinejmenším část škol dokáže ovlivnit výsledky žáků i nad rámec prostředí, ze kterého pocházejí. Při hledání faktorů, které v tomto směru odlišují úspěšnější školy od těch méně úspěšných, byly zkoumány mnohé potenciální proměnné a zvolena řada metodologických príistupů. Vedle očekávatelných charakteristik přímo ovlivňujících vyučování a učení (např. metody výuky), které v tomto textu označujeme jako akademické, se do hledáčku dostaly i faktory vypovídající o dalších charakteristikách školy týkajících se např́klad vztahů mezi aktéry školního života, které $v$ tomto textu označujeme jako neakademické.

Z nich jsme si pro náš výzkum vybrali oblast školního klimatu, konkrétně jeho percepci učiteli. Školní klima je obvykle používáno jako zastřešující termín pro řadu proměnných, které vypovídají o akademických i neakademických charakteristikách školy. Jedni z prvních výzkumníků, kteří se pokusili ukázat vliv školního klimatu na výsledky žáků, byli Brookover et al. (1978), kteří školní klima definovali jako „soubor norem a očekávání, které jsou definované a vnímané ve škole“" pojetí školního klimatu od osmdesátých let minulého století intenzivně vyvíjelo, jak konstatovali ve své přehledové studii Wang a Degolová (2016), neexistuje jedna sdílená definice školního klimatu. Existuje shoda, že se jedná o multidimenzionální koncept, přičemž přístupy jednotlivých výzkumníků se liší v tom, jaké dimenze akcentují a jak je definují. Výzkumníci upozornili, že spektrum definic je poměrně široké - od sdílených přesvědčení, hodnot a postojů, které formují interakce mezi žáky a dospělými a nastavují parametry pro přijatelné chování a normy (Brookover et al., 1978), až po poměrně abstraktní „srdce a duše školy“ (Freiberg \& Stein, 1999, cit. podle Wang \& Degol, 2016). U nás o možných prístupech ke konceptualizaci školního klimatu obsáhle pojednal napríklad Ježek (2003).

Wang a Degolová (2016) školní klima konceptualizovali ve čtyřech základních dimenzích: dimenze týkající se vzdělávání (např. vyučování a učení, leadership, profesní rozvoj učitelů), komunitní (např. kvalita vztahů, postoj k rozmanitosti ve společnosti, partnerství), institucionální (struktura organizace, adekvátní prostředí, dostupnost zdrojů apod.) a dimenze bezpečí (např. fyzické a emocionální bezpečí, rád a kázeň). Konceptualizaci se $v$ teoretické rovině pokusily dál posunout Rudasillová et al. (2018), které se snažily zohlednit implicitní východiska dosavadních př́stupů a nabídly definici stavějící na kognitivní a afektivní percepci přesvědčení, hodnot, vztahů a sociálních interakcí žáků, učitelů a dalších pracovníků školy. Vydělily tak dvě úzce provázané oblasti: hluboko ležící a často neuvědomované přesvědčení

8 V originálním znění ,the set of norms and expectations that were defined and perceived by individuals within the school“. 
a hodnoty, které se navenek promítají jak do krátkodobých sociálních interakcí, tak do déle trvajících vztahů viditelně formujících školní klima.

Měření školního klimatu se setkává s řadou obtiží. První skupina problémů plyne $z$ různorodé konceptualizace pojmu. Různým pojetím konceptu ovšem problémy zdaleka nekončí - nástroje, které se pro měření klimatu používají, vykazují řadu neduhů. Ramelowová, Currieová a Felderová-Puigová (2015) ve své přehledové studii upozornily, že i když jednotlivé nástroje mají dobré či alespoň přijatelné charakteristiky, pokud jde o jejich reliabilitu, vyznačují se nedostatečným testováním validity, chybějícím popisem teoretických východisek a nepokrývají dostatečně všechny zamýšlené domény konceptu. Tyto neduhy jasně vyplývají i z obsáhlého přehledu nástrojů k měření psychosociálního klimatu, který vypracoval Mareš (2004).

Většina studií, které se zabývají vlivem školního klimatu, se zaměřuje na zkoumání vztahu výsledků žáků a percepce klimatu žáky, daleko méně se jich věnuje učitelské percepci, př́padně srovnání žákovského a učitelského vnímání. Percepce klimatu učiteli má vztah nejenom k jejich spokojenosti v práci (např. Malinen \& Savolainen, 2016), osobní pohodě (např. Gray, Wilcox, \& Nordstokke, 2017), vlastní vnímané účinnosti (mj. Aldridge \& Fraser, 2015), vnímanému stresu (Collie, Shapka, \& Perry, 2012), syndromu vyhoření (Grayson \& Alvarez, 2008), ale také k výsledkům žáků (Brand et al., 2008). Výše zmiňované studie tedy ukazují, že zabývat se školním klimatem $z$ pozic učitele může přinést zajímavé poznatky $i$ vzhledem $\mathrm{k}$ výsledkům žáků i s ohledem na spokojenost učitelů.

Ze širokého spektra možností, jak nahlížet vnímání školního klimatu učiteli, jsme si vybrali koncept akademického optimismu9 . I když i toto pojetí vykazuje některé nedostatky, které popsaly předchozí přehledové studie, považujeme je za užitečné především proto, že nabízejí relativně stručný nástroj pro zjišt’ování vybraných aspektů školního klimatu, který se $v$ českém prostředí již ukázal jako funkční pro nižší sekundární stupeň, přičemž koncept má relativně velký potenciál vzhledem k př́padné intervenci.

Akademický optimismus vychází z přesvědčení jednotlivých učitelů ohledně důležitých aspektů učitelského povolání. Uplatňuje se však nejen na úrovni jednotlivých učitelů, ale i jako sdílená charakteristika celého učitelského sboru, která spoluutváří klima školy. Výzkumy prokázaly př́znivý dopad akademického optimismu učitelů na výsledky žáků i po zohlednění socioekonomického statusu a počátečních výsledků žáků (např. Hoy, Tarter, \& Woolfolk Hoy, 2006; Smith \& Hoy, 2007).

$\checkmark$ České republice byla baterie na měření akademického optimismu validizována v roce 2017 pro nižší sekundární stupeň vzdělávání jako charakteristika školy (Straková, Simonová, \& Greger, 2017). Autoři zároveň ukázali vztah mezi akademickým optimismem a výsledky v kognitivních testech na nižší sekundární úrovni vzdělávacího

9 Př́davné jméno akademický je použito ve smyslu „vztahující se ke vzdělávacím výsledkům“. Uvědomujeme si, že termín akademický optimismus (doslovně přeložený z angličtiny) je $v$ českém prostředí přijímán s určitými rozpaky. Přemýšleli jsme o tom, zda jej nemáme nahradit pojmem „vzdělávací optimismus“ nebo „učitelský optimismus“. Rozhodli jsme se setrvat u původního označení, nebot' koncept byl validován pod tímto označením a zároveň se nám zdá, že název akademický optimismus nejlépe vystihuje povahu konceptu. 
76 systému (Straková, Simonová, \& Greger, 2018). Cílem této studie je ověřit, zda je možné akademický optimismus využít i při hledání faktorů, které ovlivňují výsledky vzdělávání žáků v gymnaziálním a středním odborném studiu. Zjišt’ujeme, zda se přesvědčení učitelů operacionalizovaná jako akademický optimismus uplatňují nad rámec složení žáků třídy z hlediska socioekonomického statusu a počátečních výsledků. Cílem je prozkoumat, do jaké míry se z hlediska dopadu akademického optimismu liší gymnaziální a odborné programy v matematice a ve čtenářské gramotnosti.

\section{Akademický optimismus}

Akademický optimismus (např. Hoy et al., 2006; McGuigan \& Hoy, 2006; Woolfolk Hoy, Hoy, \& Kurz, 2008) je latentní konstrukt sestávající ze tří souvisejících konceptů. První koncept, vlastní účinnost ${ }^{10}$ vnímaná učitelem, je kognitivní povahy. Charakterizuje učitelovo vědomí vlastních schopností žáky motivovat pro školní práci a efektivně je vzdělávat. Druhá složka, důvěra $k$ žákům a jejich rodičům, je postojová a charakterizuje ochotu učitelů navazovat s žáky a jejich rodiči vztahy založené na čestnosti a otevřenosti. Ukazuje, do jaké míry učitelé důvěřují tomu, že jejich žáci jsou otevření učení, mají schopnost porozumět vyučovaným konceptům a jsou čestní, a do jaké míry učitelé věří, že se mohou spolehnout na podporu jejich rodičů. Třetí složka, důraz na vzdělávací výsledky, je konativní a vypovídá o tom, do jaké míry učitel trvá na svědomité a důkladné práci žáků a zda klade na žáky přiměřeně vysoké nároky.

Všechny výše popsané složky akademického optimismu spolu souvisejí a vzájemně se posilují. Např́klad pokud se učitel domnívá, že se mưže spolehnout na podporu rodičů svých žáků, mưže nastavit vysoké požadavky, nebot' věří, že jeho snaha nebude rodiči zpochybňována. Vysoké nároky, které přinášejí výsledky, na druhé straně posilují učitelovu důvěru ve vlastní schopnosti (Hoy et al., 2006). Kombinování všech tř́ výše popsaných složek do jednoho společného konceptu je rovněž výhodné proto, že ukazuje, že při snaze o zlepšení výsledků bychom měli dbát na všechny tři složky zároveň. To znamená snažit se zvyšovat dovednosti učitelů a jejich sebedůvěru, posilovat důvěru mezi rodinou a školou a neslevovat z nároků na svědomitou práci žáků.

Výzkumy $v$ řadě odlišných vzdělávacích systémů prokázaly, že akademický optimismus učitelů má pozitivní dopad na výsledky žáků bez ohledu na jejich socioekonomický status, jejich předchozí vzdělávací výsledky a jejich další rozmanité demografické charakteristiky (např. Anwar \& Anis-ul-Haque, 2014; Bevel \& Mitchell, 2012; Boonen et al., 2014; Eren, 2014; Chang, 2011; Kirby \& DiPaola, 2011; Kösterelioğlu, 2017; Mascall et al., 2008; Moghari et al., 2011; Ngidi, 2012; Sezgin \& Erdogan, 2015; Smith \& Hoy, 2007; Wu, 2013; Wu, Hoy, \& Tarter, 2013). V rámci výzkumu TIMSS 2011 byl prokázán statisticky významný dopad modifikovaného

10 Vlastní účinnost (self-efficacy) učitele bývá v pedagogickém a psychologickém výzkumu zkoumána samostatně. Do konceptu akademického optimismu vstupuje spolu s dalšími dvěma složkami. 
ukazatele akademického optimismu (důraz školy na studijní úspěch - school emphasis on academic success - SEAS ${ }^{11}$ ) v primární škole ve většině zemí, které se výzkumu TIMSS zúčastnily (Martin et al., 2013).

V České republice byl koncept akademického optimismu zkoumán na nižším sekundárním stupni vzdělávání. Straková et al. (2018) ukázali na výběru 1469 učitelů ze 124 základních škol a z 39 víceletých gymnázií, že baterie na měření individuálního akademického optimismu, kdy se učitelů dotazujeme na jejich vlastní postoje (Fahy, Wu, \& Hoy, 2010), dobře funguje v českých podmínkách při měření profesních přesvědčení učitelů nižšího sekundárního stupně vzdělávání. Zároveň potvrdili, že se akademický optimismus v české škole uplatňuje na úrovni individuálních učitelů i na úrovni celých učitelských kolektivů, tedy že učitelé do určité míry přesvědčení ohledně učitelské profese sdílejí v rámci školy. A to i přesto, že zdůrazňují, že se přístupy jednotlivých učitelů významně liší.

Čeští výzkumníci dále potvrdili statisticky významný vztah mezi akademickým optimismem učitelů a vzdělávacími výsledky žáků v matematice. Ukázali, že postoje učitelů souvisejí se složením žáků z hlediska jejich rodinného zázemí i vzdělávacích výsledků a že tyto postoje ovlivňují výsledky žáků. To znamená, že ve školách s průměrně vyšším socioekonomickým statusem a průměrně lepšími vzdělávacími výsledky žáků je průměrně vyšší úroveň akademického optimismu učitelů, což dále přiznivě ovlivňuje vzdělávací výsledky. Akademický optimismus učitelů se tak stává dalším faktorem, který zvyšuje rozdíly mezi jednotlivými školami.

\section{Výzkumné cíle}

Tato studie má dva hlavní cíle:

1) ověřit funkčnost konceptu akademického optimismu pro učitele středních škol a zjistit, zda mezi jednotlivými typy středoškolského studia existují rozdíly z hlediska reportovaného akademického optimismu jejich učitelů;

2) zjistit, zda existuje vazba mezi reportovaným akademickým optimismem a výsledky středoškoláků $v$ testech $z$ matematiky a ze čtenářské gramotnosti, zohledníme-li složení žáků z hlediska socioekonomického statusu, jejich počátečních výsledků a typ studia.

Vycházíme $z$ toho, že se středoškolské programy v ČR velmi liší z hlediska vzdělávacích cílů, kurikula, sociálního složení žáků a jejich kognitivních a nekognitivních výsledků. Zajímá nás, do jaké míry se gymnaziální a odborné programy různí reportovaným klimatem, který zde primárně charakterizujeme prostřednictvím akademického optimismu. Dále nás zajímá, zda akademický optimismus učitelů přispívá

11 Index SEAS byl měřen na úrovni školy, tedy jako agregované odpovědi všech učitelů. Sestával z následujících komponent: porozumění kurikulárním cílům, vnímaná vlastní účinnost při implementaci školního kurikula, očekávání učitelů ve vztahu k výsledkům žáků, učiteli vnímaná podpora rodičů při dosahování dobrých vzdělávacích výsledkủ žáků a učiteli vnímaná snaha žáků dosahovat dobrých vzdělávacích výsledků. 
$78 \quad \mathrm{k}$ rozdílným výsledkům $\mathrm{v}$ obou typech studia, tedy zda jsou vzdělávací výsledky ovlivněny i klimatem prostředí, ve kterém výuka probíhá.

$\checkmark$ této práci rozlišujeme pouze mezi gymnaziálním a odborným studiem, přičemž do odborného studia řadíme maturitní i nematuritní obory. $V$ našem výzkumném souboru rozlišujeme mezi maturitními a nematuritními obory, nicméně tyto obory jsou velmi často vyučovány na stejných školách. Učitelé nebyli dotazováni vzhledem k oboru, ve kterém vyučují, jednotkou agregace je pro nás tedy škola a ta umožňuje diferencovat pouze mezi gymnaziálním a odborným studiem.

Souvislosti mezi uvedenými faktory zkoumáme pro dva odlišné typy vzdělávacích výsledků: pro matematiku, která se $\mathrm{v}$ jednotlivých programech značně liší obsahem i náročností, a pro čtenářskou gramotnost, kterou střední škola pravděpodobně již cíleně nerozvíjí, ale na výstupu ze středoškolského studia by jí měli být vybaveni všichni žáci.

\section{Data, metody}

Data využívaná $v$ této studii byla získána v rámci longitudinálního výzkumu CLoSE (Czech Longitudinal Study in Education ${ }^{12}$ ). V rámci tohoto výzkumu proběhlo na podzim 2016 šetření na výběru žáků $v 1$. ročnících středoškolského studia a na přelomu let 2018/2019 šetření rozšířeného vzorku žáků středních škol v polovině 3. ročníku. ${ }^{13}$ Žákům byly administrovány dotazníky a testy ze čtenářské gramotnosti, matematiky a českého jazyka. Ve školním roce 2018/2019 vyplňovali učitelé vyučující testované žáky $v$ zúčastněných školách učitelské dotazníky.

\subsection{Výběr respondentů}

Do dotazníkového šetření v roce 2018 se zapojilo 809 učitelů ze 104 škol. Do analýzy nicméně vstoupilo pouze 795 učitelů z 91 škol, nebot' jsme pracovali jen se školami, kde dotazník vyplnilo minimálně pět vyučujících. Na tomto souboru jsme ověřovali funkčnost konceptu akademického optimismu pro učitele ve vyšším sekundárním vzdělávání.

Pro zkoumání vztahu mezi akademickým optimismem a výsledky žáků jsme využili soubor žáků, kteří se zapojili do výzkumu v obou vlnách. Výběr žáků byl v roce 2016 proveden dvoustupňově, nejprve byly náhodně vybírány střední školy, následně jedna až dvě třídy $v$ těchto školách. Výběr byl stratifikován podle regionu, typu studia (gymnaziální, střední odborné s maturitou, střední odborné bez maturity) a dle regionu. Gymnazisté byli ve výzkumu nadreprezentováni, z toho důvodu byla

12 Vztahy mezi dovednostmi, vzděláváním a výsledky na trhu práce: longitudinální studie (číslo P402/12/G130).

13 Výběr zapojený do výzkumu v roce 2016 byl rozšiřen o další odborné školy tak, aby lépe reprezentoval populaci žáků středních škol. Ve výběru z roku 2016 byli nadreprezentováni gymnazisté. Učitelský dotazník byl administrován ve všech školách, které se zapojily do výzkumu v roce 2018. 
data převážena podle zastoupení v jednotlivých typech studia. Při výběru nebylo rozlišováno mezi tř́́dami čtyřr- a víceletých gymnaziálních programů, žáci víceletých gymnázií byli nicméně ve výběru zastoupeni tak, jak odpovídá jejich podílu v populaci gymnazistů. Šetření v obou vlnách se zúčastnilo 2846 žáků ze 143 tříd v 79 školách (50 odborných škol a 29 gymnázií). Do analýzy vstoupilo 2320 žáků z 66 škol, ve kterých vyplnilo minimálně pět učitelů dotazník, který měřil úroveň akademického optimismu. Složení výsledného datového souboru uvádíme v tabulce 1.

Tabulka 1 Složení datového souboru pro výpočet vztahu mezi akademickým optimismem a výsledky $v$ testech

\begin{tabular}{lccccc}
\hline & Školy & Tř́dy & Žáci (nevážení) & Žáci (vážení) & Počet učitelů \\
\cline { 2 - 6 } Celkem & 66 & 117 & 2320 & & \\
gymnázia & 25 & 47 & 1115 & 580 & 208 \\
odborné školy & 41 & 70 & 1205 & 1740 & 336 \\
\hline
\end{tabular}

\subsection{Výzkumné nástroje}

Žáci byli testováni z matematiky, z českého jazyka a ze čtenářské gramotnosti. $V$ této studii využíváme výsledky z testů z matematiky a ze čtenářské gramotnosti, které byly koncipovány tak, aby test jako celek byl schopen zachytit vývoj ve vědomostech a dovednostech mezi 1. a 3. ročníkem. Testy byly vždy vyvinuty ve dvou paralelních variantách A a B, aby bylo eliminováno opisování. Oba obsahovaly zhruba 30 úloh, $z$ toho polovinu otevřených, vyžadujících vlastní odpověd' ( $v$ matematice převážně čiselnou, ve čtenářské gramotnosti stručnou či rozšířenou slovní odpověd'), a polovinu uzavřených otázek s výběrem odpovědi. Matematické úlohy pokrývaly tři obsahové okruhy učiva: 1) číslo a početní operace; 2) závislosti, vztahy a práce s daty; a 3) geometrie $v$ rovině a prostoru. Většina zadání byla inspirována úlohami $z$ výzkumu TIMSS nebo $z$ testů společné části maturitní zkoušky.

$V$ testu čtenářské gramotnosti byly použity uvolněné úlohy $z$ testů čtenářské gramotnosti výzkumu PISA a autorská zadání. Každý sešit obsahoval šest výchozích textů, k nimž se vztahovalo od tř́ do šesti úloh. Úlohy byly zaměřeny na tři oblasti čtenářských dovedností: vyhledávání informací obsažených v textu, vyvozování závěrů (hledání vnitřních souvislostí a vztahů $v$ daném textu) a zhodnocení textu (propojování $s$ informacemi, které nejsou $v$ textu obsaženy). Výsledky obou testů byly vyjádřeny prostřednictvím procentuální úspěšnosti.

Žáci dále vyplňovali dotazník mapující jejich rodinné zázemí, školní zkušenosti a postoje ke škole a vzdělávání. Zde využíváme otázky, ze kterých byla zkonstruována proměnná charakterizující socioekonomický status žáka: 1) otázky zjišt'ující vzdělání matky a vzdělání otce na čtyřstupňové škále: 1 - základní, 2 - střední bez maturity, 3 - střední s maturitou, 4 - vysokoškolské; 2) otázky dotazující se na povolání matky a povolání otce, které byly kódovány dle klasifikace ISCO (International Standard 
80 Classification of Occupations) $)^{14}$; a 3) otázku zjišt'ující počet knih v domácnosti (6 kategorií: 1 - 0-10 až 6 - více než 500). Proměnná charakterizující socioekonomický status byla vypočtena jako faktorový skór výše uvedených proměnných (faktorový skór vysvětluje 51 \% rozptylu proměnných). Vy̌šsí hodnota indikuje vyšší socioekonomický status.

Akademický optimismus učitelů byl zjišt’ován prostřednictvím devítipoložkové baterie, $v$ niž byla každá ze tř́ složek konceptu (vnímaná účinnost, důvěra v žáky a jejich rodiče a důraz na vzdělávací výsledky) zjištována třemi výroky. Učitelé byli vyzváni, aby vyjádřili míru souhlasu s jednotlivými výroky na škále: 1 - rozhodně nesouhlasím až 6 - rozhodně souhlasím..$^{15}$ Znění jednotlivých položek i se základními statistikami uvádíme ve výsledkové části. $Z$ trojic položek byly vypočteny faktorové skóry. Indikátor akademického optimismu byl následně vypočítán jako školní průměr faktorových skórů u učitelů, kteří ve škole vyučují.

\subsection{Metody analýzy dat}

Na souboru 795 učitelů byla nejprve provedena konfirmační faktorová analýza s cílem ověřit, zda koncept akademického optimismu funguje u středoškolských učitelů stejně jako u učitelů nižšího sekundárního stupně. Konfirmační faktorová analýza byla počítána $v$ programu Mplus. Pro jednotlivé položky akademického optimismu byly dále vypočteny koeficienty vnitrotřídní korelace (ICC) s cílem ukázat, jak moc se položky liší mezi jednotlivými školami (koeficient udává, jaký podíl rozptylu v jednotlivých položkách můžeme vysvětlit rozdíly mezi školami).

V druhém kroku byl testován dvouúrovňový strukturní model, který ověřoval vztahy mezi výsledky žáků, jejich rodinným zázemím, typem studia, složením žáků a akademickým optimismem jejich učitelů.

Dvouúrovňový model s první úrovní žákovskou a druhou úrovní školní byl zvolen $z$ toho důvodu, že některé faktory, které mohou potenciálně ovlivňovat vzdělávací výsledky, se uplatňují na úrovni žáka a jiné na úrovni školy. Dvouúrovňový model nám tedy umožňuje vysvětlovat výsledky ve 3. ročníku studia nejen prostřednictvím socioekonomického statusu žáka samého a jeho výsledků v 1. ročníku (individuální úroveň), ale také pomocí složení spolužáků, postojů učitelů a typu studia (školní úroveňn) ${ }^{16}$.

Strukturní model zároveň umožňuje modelovat vztahy mezi proměnnými $v$ jednotlivých úrovních. Umožňuje tedy např́klad ověřovat, jak souvisí postoje učitelů se složením žáků nebo s typem studia při zohlednění ostatních proměnných.

Jako závislé proměnné byly využity výsledky $v$ testech čtenářské gramotnosti, respektive matematiky ve 3. ročníku studia. Dále uvádíme nezávislé proměnné, které vstupovaly do modelu na úrovni žáka a na úrovni školy.

14 Na základě odpovědí na dvojici otázek: Jaké je hlavní zaměstnání tvého otce? Co tvůj otec $\checkmark$ zaměstnání dělá? - byly vygenerovány čtyřmístné kódy klasifikace ISCO. Při výpočtu byly využity první číslice, které tvoří hierarchický systém (9 kategorií).

15 Byly popsány pouze krajní body škály.

16 Realizované simulační studie (např. Maas \& Hox, 2005) ukazují, že při uvedeném typu výpočtu by neměl počet jednotek na druhé úrovni klesnout pod 50 a že by na druhé úrovni neměly být použity více než čtyři prediktory. Tato doporučení naše studie plně respektuje. 
Nezávislé proměnné, které vstupují do analýz na individuální žákovské úrovni:

- procentuální úspěšnost v matematickém testu na začátku středoškolského studia;

- procentuální úspěšnost ve čtenářském testu na začátku středoškolského studia;

- socioekonomický status (ses).

Nezávislé proměnné, které vstupují do analýz na úrovni školy:

- studijní úroveň žáků školy - výsledek v matematickém testu na začátku středoškolského studia agregovaný na úroveň školy, respektive výsledek ve čtenářském testu na začátku středoškolského studia agregovaný na úroveň školy;

- socioekonomické složení žáků školy - socioekonomický status agregovaný na úroveň školy;

- akademický optimismus učitelů školy;

- gymnaziální studium (jako protiklad ke studiu odbornému).

Jsme si vědomi určitého limitu zpưsobeného tím, že akademický optimismus byl měřen až ve 3 . ročníku, nikoli $v 1$. ročníku, ale vycházíme $z$ toho, že postoje učitelů i klima učitelských sborů jsou v čase spíše stabilní, tedy stejným způsobem ovlivňovaly žáky $v$ průběhu celého studia.

Výpočty byly provedeny v programu Mplus. Kvalita modelů byla posuzována podle ukazatelů RMSEA ${ }^{17}, \mathrm{TLI}^{18}, \mathrm{CFI}^{19}$ a SRMR ${ }^{20}$. Pro úplnost uvádíme u jednotlivých modelů rovněž hodnotu $\chi^{2}$ testu ${ }^{21}$.

\section{Výsledky}

\subsection{Ověření konceptu akademického optimismu v populaci středoškolských učitelů}

Na souboru učitelů byla provedena jednoúrovňová konfirmační faktorová analýza. Akademický optimismus $(\mathrm{AO})$ byl tvořen třemi latentními faktory: vnímaná účinnost (VU), důvěra v žáky a jejich rodiče (D) a důraz na vzdělávací výsledky (VV),

17 Root mean square error of approximation udává, jak dobře model odpovídá populační kovarianční matici. Hu a Bentler (1999) považují pro vyhovující modely za maximální hodnotu RMSEA 0,06.

18 Tucker-Lewis index hodnotí model na základě porovnání hodnoty $\chi^{2}$ odhadovaného modelu a $\chi^{2}$ nulového modelu (modelu nezávislosti).

19 Comparative Fit index je analogický indexu TLI (tj. srovnává odhadovaný model a model nezávislosti) s tím, že bere v úvahu též velikost výběru. Hu a Bentler (1999) považují za doklad dobré shody s daty $v$ prípadě ukazatelů TLI a CFI hodnoty vyšší než 0,9 .

20 Standardized root mean square residual je druhá odmocnina z rozdílu mezi rezidui kovarianční matice a hypotetického kovariančního modelu. Za indikaci dobrého modelu je považována hodnota 0,05 a nižší (např. Byrne 1998).

21 Test srovnává kovarianční matici ze získaných dat a kovarianční matici, která vznikne při užití modelu. Tento test je citlivý jednak na velikost souboru (pro větší datové soubory typicky vede k zamítání hypotézy o shodě kovariančních matic) a jednak komplikovanost modelu (pro složitější modely vede zpravidla k zamítání hypotézy o shodě kovariančních matic). Výsledky testu uvádíme zejména pro úplnost posouzení, některá z výše uvedených kritérií (CFI, TLI) vycházejí z hodnoty tohoto testového kritéria a odstraňují jeho citlivost na velikost datového souboru, resp. komplexnost modelu. 
82 přičemž každý faktor byl sycen třemi položkami. Model vykazoval přijatelné parametry: $\mathrm{RMSEA}=0,079, \mathrm{CFI}=0,940, \mathrm{TLI}=0,909, \mathrm{SRMR} 0,05, \chi^{2}$ test 143,993 při 24 stupních volnosti. Všechny vazby $v$ modelu byly statisticky významné na úrovni 0,05 . Výsledky uvádíme $v$ tabulce 2 .

Tabulka 2 Konfirmační faktorová analýza - akademický optimismus $(N=795)$

\begin{tabular}{lccc}
\hline & $\begin{array}{c}\text { Vnímaná účinnost učitelů } \\
(\mathrm{VU})\end{array}$ & $\begin{array}{c}\text { Důvěra učitelů k žákům } \\
\text { a jejich rodičům }(\mathrm{D})\end{array}$ & $\begin{array}{c}\text { Důraz učitelů na vzdělávací } \\
\text { výsledky }(\mathrm{VV})\end{array}$ \\
\cline { 2 - 4 } VU1 & 0,702 & & \\
VU2 & 0,757 & & \\
VU3 & 0,533 & 0,779 & \\
D1 & & 0,680 & 0,437 \\
D2 & & 0,707 & 0,768 \\
D3 & & & 0,825 \\
VV1 & & 0,621 \\
VV2 & & & \\
VV3 & 0,747 & 0,718 & \\
A0 & & & \\
\hline
\end{tabular}

Konfirmační analýza potvrdila, že akademický optimismus lze konstruovat dvoustupňově prostřednictvím tři faktorů sycených třemi položkami. Pro každého učitele jsme pomocí faktorové analýzy zkonstruovali jednotlivé složky a následně též výsledný ukazatel akademického optimismu. $v$ tabulce 3 uvádíme průměry a směrodatné odchylky pro položky, které sytí jednotlivé latentní proměnné pro celý soubor a zvlášt' pro jednotlivé typy škol (odborné školy, gymnázia). U jednotlivých položek uvádíme rovněž hodnoty koeficientu vnitrotřídní korelace (ICC), které ukazují, jaký podíl rozdílů $v$ jednotlivých položkách je dán rozdíly mezi školami.

Z tabulky vyplývá, že učitelé gymnázií smýšlejí celkově poněkud pozitivněji o své práci i o svých žácích. Zároveň vidíme, že mezi jednotlivými školami existují významné rozdíly $v$ postojích učitelů, přičemž největší rozdíly shledáváme $v$ latentní proměnné charakterizující míru důvěry $v$ žáky a jejich rodiče: zde zaznamenáváme nejvyšší hodnoty koeficientu ICC. 
Tabulka 3 Položky akademického optimismu $(N=795)$

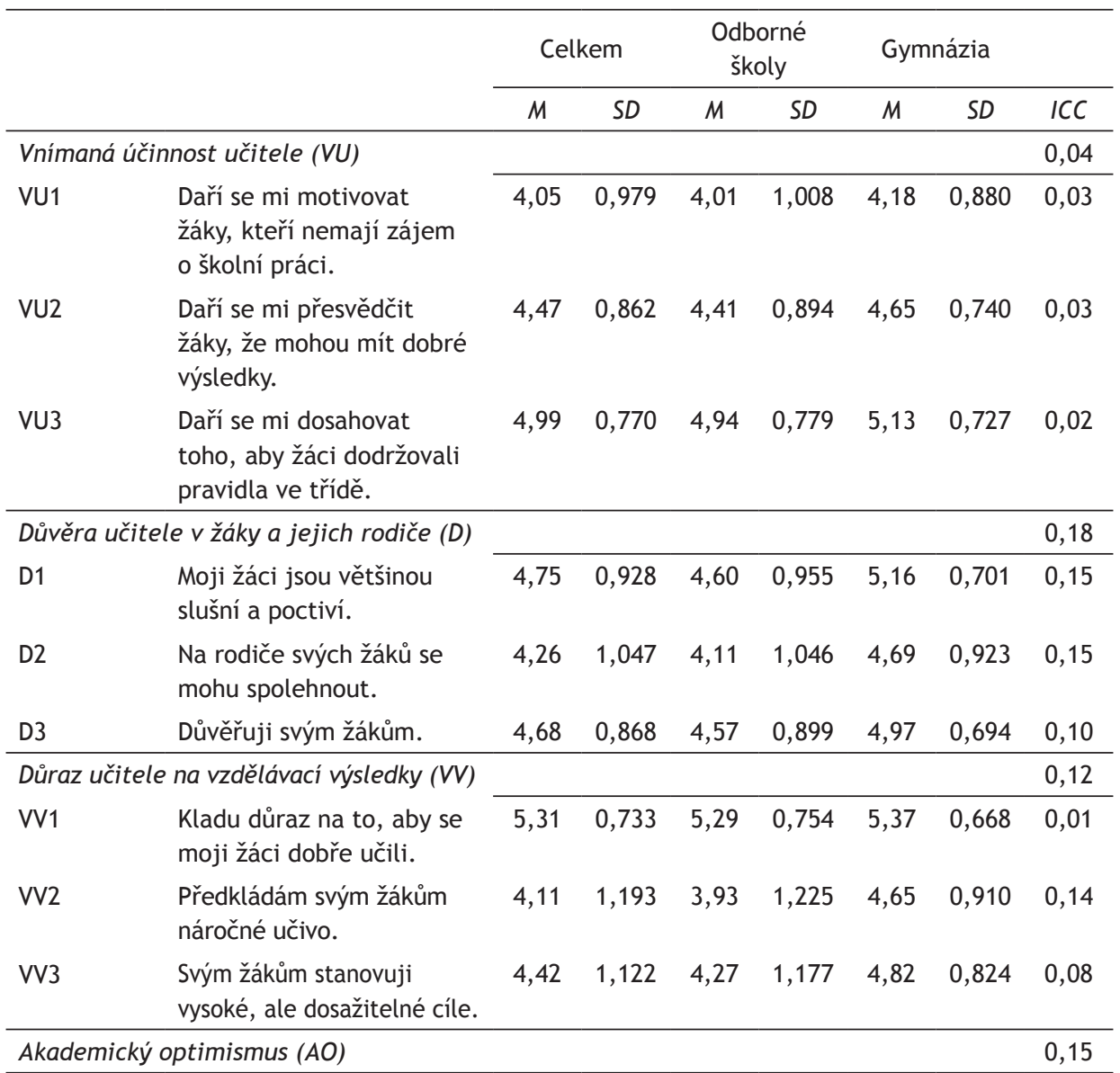

Poznámka: Učitelé uváděli souhlas s předloženými tvrzeními na šestibodové škále (1 - rozhodně nesouhlasím až 6 - rozhodně souhlasím).

\subsection{Modelování vztahu mezi socioekonomickým statusem žáků, akademickým optimismem učitelů a výsledky vzdělávání}

Hlavním cílem našich analýz bylo zjistit, do jaké míry ovlivňuje akademický optimismus testové výsledky $v$ matematice a ve čtenářské gramotnosti u žáků gymnázií a středních odborných škol a zda, eventuálně jak, se liší situace $v$ případě matematiky a čtenářské gramotnosti.

Obrázek 1 ukazuje model pro čtenářskou gramotnost. Model vykazuje dobrou shodu s daty, RMSEA $=0,029, \mathrm{CFI}=0,998, \mathrm{TLI}=0,986$, SRMR na úrovni žáka 0,000, na úrovni školy $0,041, \chi^{2}$ test dosahuje při 2 stupních volnosti hodnoty 6,540 . Model vysvětluje 41 \% rozptylu na úrovni žáka a 66 \% rozptylu na úrovni školy. 


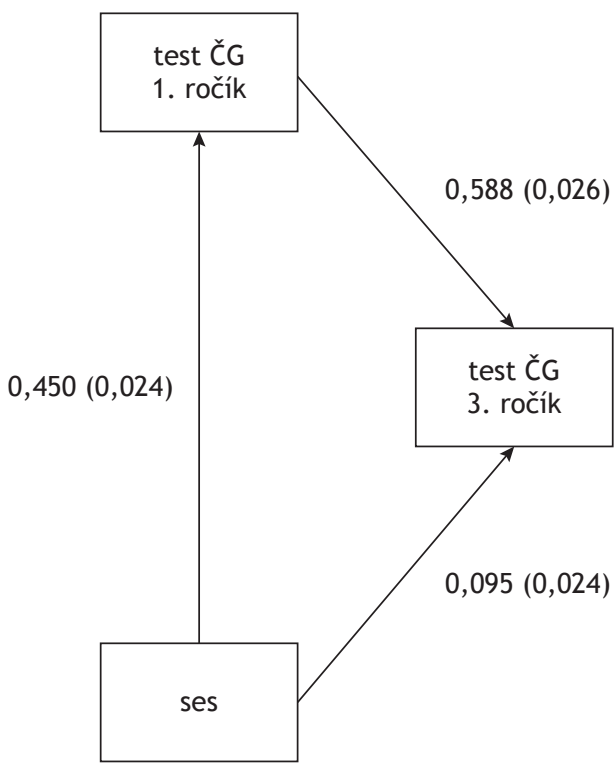

úroveň školy

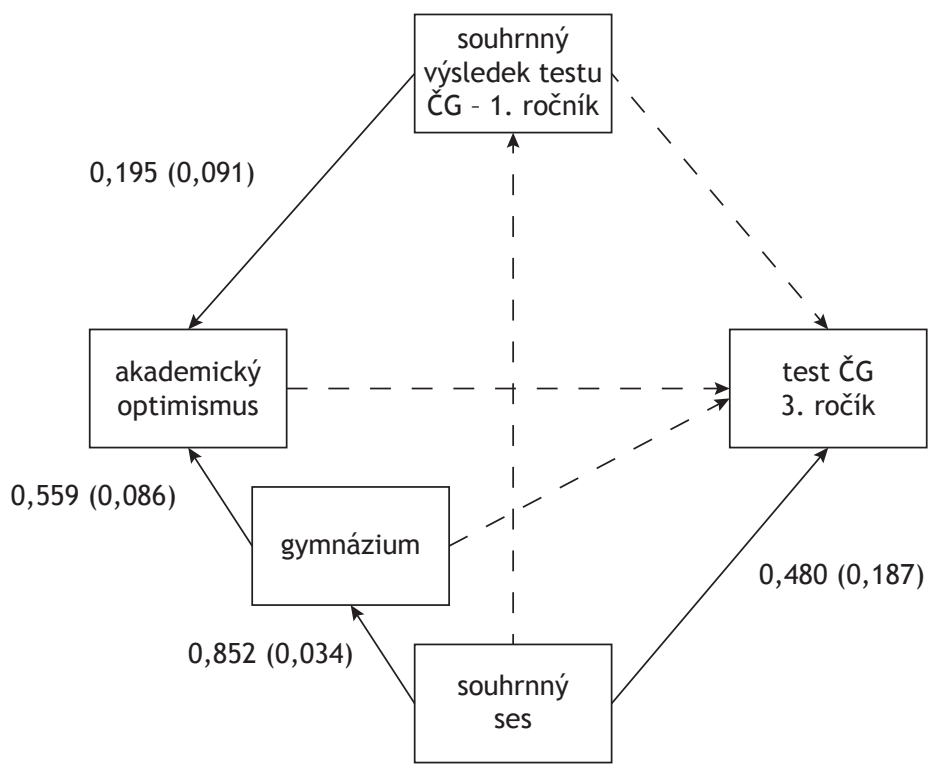

Obrázek 1. Dvouúrovňový model vztahu mezi socioekonomickým statusem žáků, akademickým optimismem učitelů, typem studia a výsledky vzdělávání ve čtenářské gramotnosti $(N=2320)$. Koeficienty jsou standardizované, v závorkách jsou uvedeny standardní chyby. 
úroveň žáka

85

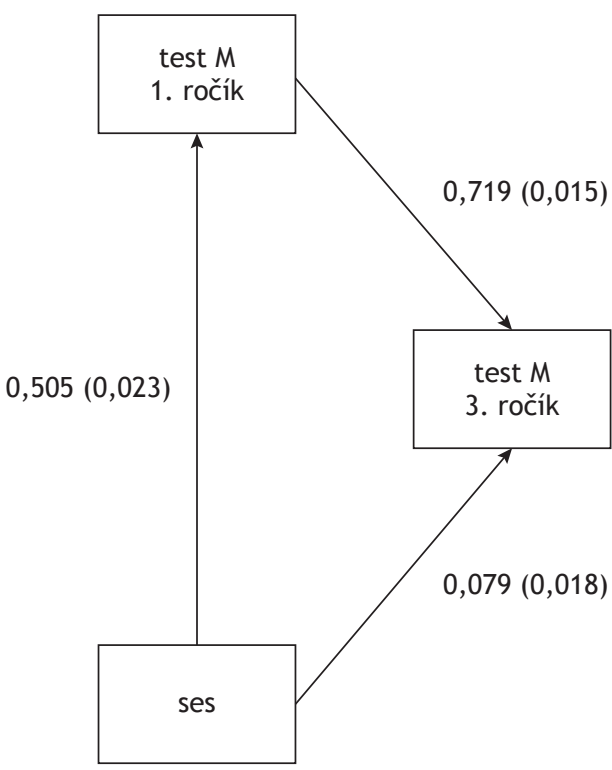

úroveň školy

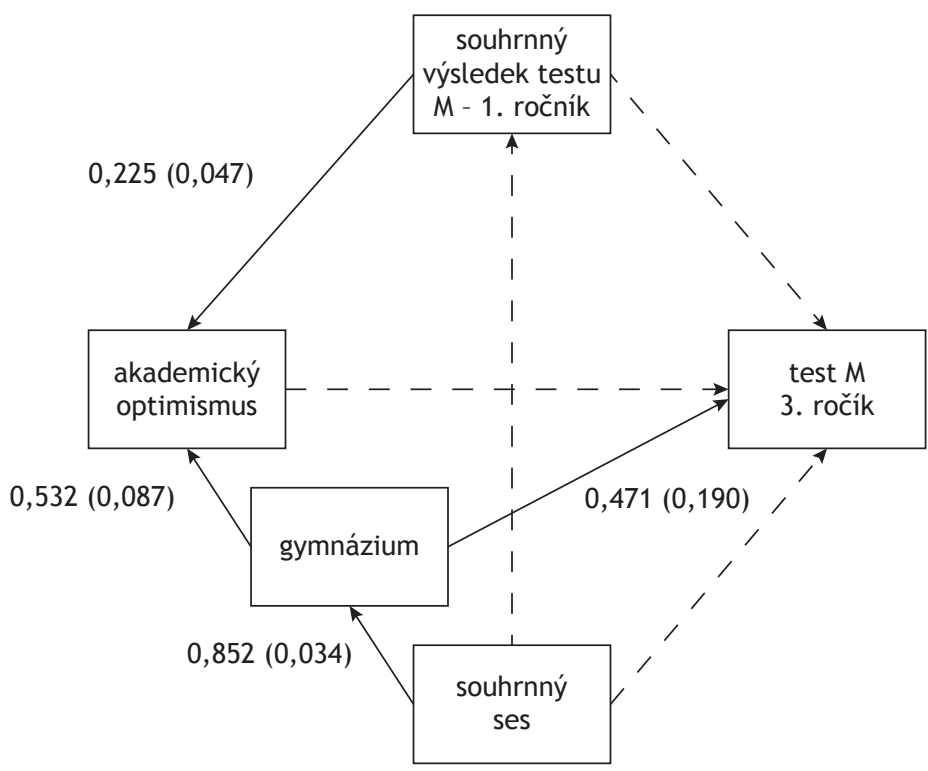

Obrázek 2. Dvouúrovňový model vztahu mezi rodinným zázemím žáků, akademickým optimismem učitelů, typem studia a výsledky vzdělávání v matematice $(N=2320)$. Koeficienty jsou standardizované, v závorkách jsou uvedeny standardní chyby. 
Šipky v obrázku ukazují vazby mezi jednotlivými proměnnými v obou úrovních. Vztahy, které se neprokázaly jako statisticky významné, jsou vyznačeny čárkovaně. $Z$ obrázku je žrejmé, že na úrovni žáka jsou všechny vazby statisticky významné. Výsledek $v$ testu čtenářské gramotnosti ve 3 . ročníku je ovlivněn výsledkem $\checkmark 1$. ročníku a socioekonomickým statusem žáka. Socioekonomický status ovlivňuje rovněž výsledek $v 1$. ročníku. Na úrovni školy je výsledek ovlivněn pouze socioekonomickým složením žáků. Neuplatňuje se ani studijní úroveň žáků charakterizovaná agregovaným výsledkem $v 1$. ročníku, ani akademický optimismus, ani typ studia. Akademický optimismus je nicméně statisticky významně vyšší u gymnaziálního studia, které má žáky s vyšším socioekonomickým statusem, a je pozitivně ovlivňován studijní úrovní žáků.

Obrázek 2 představuje model pro matematiku. I tento model vykazuje dobrou shodu s daty. Zde je RMSEA $=0,037, \mathrm{CFI}=0,998, \mathrm{TLI}=0,984$, SRMR na úrovni žáka 0,000 , na úrovni školy $0,035, \chi^{2}$ test dosahuje při 2 stupních volnosti hodnoty 9,444 . Model vysvětluje 58 \% rozptylu na úrovni žáka a 51 \% rozptylu na úrovni školy.

Na úrovni žáka jsou vazby mezi proměnnými podobné jako u čtenářské gramotnosti. Na školní úrovni je nicméně obrázek poněkud odlišný v tom smyslu, že výsledek je statisticky významně vyšší u gymnaziálního studia. Socioekonomické složení žáků se na něm př́mo nepodílí, jeho vliv je pouze zprostředkovaný přes typ studia. Ani tady se neuplatňuje akademický optimismus učitelů, i zde se však potvrzuje, že je statisticky významně vyšší v gymnaziálním programu a ve škole s vyšší studijní úrovní žáků.

Modely prokázaly, že akademický optimismus učitelů se pro gymnázia a střední odborné školy liší a je ovlivněn studijním složením žáků školy. Neprokázaly však (při kontrole dalších proměnných) vliv akademického optimismu učitelů na výsledky žáků ani $\vee$ matematice, ani ve čtenářské gramotnosti. Zároveň výsledky ukázaly, že na úrovni školy se liší faktory, které dominantně ovlivňují výsledky žáků v matematice a čtenářské gramotnosti. Zatímco ve čtenářské gramotnosti jsou výsledky ovlivněny primárně socioekonomickým statusem žáka, v matematice tuto roli má typ studia.

\section{Diskuse a závěr}

Cílem této práce bylo ověřit funkčnost konceptu akademického optimismu na úrovni české střední školy a zjistit, zda se liší pro gymnaziální a odborné studium a jestli ovlivňuje výsledky vzdělávání v matematice a ve čtenářské gramotnosti.

Konfirmační faktorová analýza provedená na datech získaných od 795 učitelů 3. ročníků středních škol ukázala, že koncept akademického optimismu je na úrovni střední školy aplikovatelný ve stejné podobě, v jaké byl použit na úrovni nižšího sekundárního vzdělávání: jako latentní proměnná složená ze tří latentních proměnných, kterými jsou vnímaná vlastní účinnost učitele, důvěra $v$ žáky a $v$ jejich rodiče a důraz učitele na vzdělávací výsledky žáků, z nichž každá je sycena třemi položkami (srov. Straková et al., 2018). 
Analýza rozdílů mezi školami $\vee$ jednotlivých položkách $\mathrm{i} \vee$ hodnotách latentních proměnných ukázala větší rozdíly mezi jednotlivými školami než mezi školami vzdělávajícími žáky nižšího sekundárního stupně (srov. Straková et al., 2017, 2018) $\mathrm{z}$ hlediska důvěry $v$ žáky a jejich rodiče i $z$ aspektu nároků kladených na žáky, přičemž největší rozdíly shledáváme $v$ oblasti důvěry učitele $v$ žáky a jejich rodiče. Učitelé gymnázií vykazují poněkud příznivější charakteristiky ve všech třech oblastech, reportují vyšší pocit vlastní účinnosti, vyšší důvěru $v$ žáky a $v$ jejich rodiče a větší dưraz na vzdělávací výsledky žáků, ale i zde panují mezi jednotlivými gymnázii značné rozdíly.

Nižší hodnoty v oblasti vnímání vlastní účinnosti u začínajících učitelů učňovských škol byly nalezeny též v estonské studii (Meristo \& Eisenschmidt, 2014). Podle dalších výzkumů přitom vnímaná vlastní účinnost může být významně ovlivněna pocitem sounáležitosti učitelů se školou, kterou utváří vědomí, že mohou získat pomoc, radu a povzbuzení od kolegů a cítit se jimi akceptovaní (Aldridge \& Fraser, 2015). Vytvoření prostředí, ve kterém učitelé mohou společně pracovat a sdílet své přemýšlení, tedy může napomoci zlepšit vnímání vlastní účinnosti.

Pokud jde o oblast důvěry učitelů v žáky a jejich rodiče, vlámská studie ukázala, že míra důvěry učitelů $v$ žáky se odvíjí také od složení žáků $z$ hlediska socioekonomického zázemí: menší důvěru požívají žáci ve školách, ve kterých je socioekonomický status žáků nižší, a to nezávisle na vztahu žáků ke vzdělávání (Van Maele \& Van Houtte, 2011). Vzhledem k tomu, že české odborné školy mají vyšší podíl žáků s nižším socioekonomickým statusem, je možné, že nižší důvěru učitelů lze vysvětlit obdobným způsobem. Titíž autoři pak ve své pozdější studii ukázali, že studenti odborných škol mají podstatně nižší pocit sounáležitosti se školou, který je možné vysvětlit nižší důvěrou učitelů v žáky (Van Houtte \& Van Maele, 2012). Autoři z toho vyvozují, že zásadní pro zlepšení pocitu sounáležitosti žáků je právě zvýšení důvěry učitelů v žáky.

Inspirací pro způsoby, jakými lze důvěru zlepšovat, může být např́klad výzkum, který prostřednictvím designu zakotvené teorie sledoval utváření důvěry mezi žáky a učiteli středních škol z pohledu učitelů (Russell, Wentzel, \& Donlan, 2016). V této studii se učitelé na utváření důvěry zaměřili, nešlo tedy o pouhý vedlejší produkt procesů vyučování a učení. Zároveň věřili, že jsou to právě oni, kdo jsou odpovědní za budování důvěry, a upozorňovali na to, že se nejedná o jednorázovou akci, ale o dlouhodobý proces, ve kterém je důvěra budována a upevňována. Na budování důvěry se podílely především: ustanovení vstřícného, bezpečného a pečujícího prostředí, konzistence $v$ tom, co učitel říká a dělá, předvídatelnost, spolehlivost a férovost, komunikace očekávání pomocí stanovení hranic a pravidel, poskytnutí autonomie a možnosti výběru, pomáhající a podporující chování učitele, navázání osobního vztahu, modelování pozitivních interakcí a využití specifických metod vyučování.

Poznatek o rozdílech ve složkách akademického optimismu mezi jednotlivými typy studia i mezi školami jsou v každém případě důležité. Ukazují, že má smysl se zabývat tím, čím jsou tyto rozdíly zapřičiněny a jaký mají dopad na výsledky 
88 vzdělávání. My jsme se v této studii zaměřili na vliv akademického optimismu na vědomosti a dovednosti žáků $v$ matematice a ve čtenářské gramotnosti, které jsme měřili prostřednictvím testů. Využili jsme poznatku, že s akademickým optimismem učitelů je možné pracovat jako s charakteristikou školy (koeficienty vnitrotřídní korelace ukazují, že postoje učitelů jsou ve školách do jisté míry sdíleny), a k vysvětlení dopadu akademického optimismu na vzdělávací výsledky jsme využili dvouúrovňový model. Na úrovni žáka byl výsledek ve 3. ročníku studia vysvětlován jeho výsledkem $v 1$. ročníku a socioekonomickým statusem žáka. Na úrovni školy byl výsledek vysvětlován složením žáků školy, tedy jejich průměrným výsledkem $v 1$. ročníku a průměrným socioekonomickým statusem, dále typem studia a akademickým optimismem jejich učitelů. Sledován byl rovněž vztah mezi jednotlivými proměnnými, typicky ovlivnění akademického optimismu učitelů složením žáků a typem studia. Modely ukazují ovlivnění akademického optimismu učitelů složením žáků školy, čímž potvrzují poznatky analýz provedených na nižším sekundárním stupni (srov. Straková et al., 2018) a poznatky výše uvedených výzkumů (Van Maele \& Van Houtte, 2011).

Na rozdíl od poznatků z nižšího sekundárního stupně však nepotvrzují dopad akademického optimismu učitelů na výsledky žáků. Toto zjištění není v souladu s výzkumy prováděnými ve středních školách v USA (Hoy et al., 2006; Wagner \& DiPaola, 2011).

Při bližším pohledu na publikace, které se zabývaly vztahem výsledků žáků a akademického optimismu učitelů, se ukazuje, že se naprostá většina výzkumů zaměřila na prostředí odpovídající 1. stupni ZŠ, kde se tento vztah potvrdil, podobně jako tomu bylo i v předchozím českém výzkumu, který ověřoval vztah výsledků žáků a akademického optimismu v prostředí nižšího sekundárního vzdělávání (Straková et al., 2018).

Výsledky by mohly být interpretovány tak, že úloha akademického optimismu učitele pro výsledky na střední škole již není tak důležitá jako v povinném vzdělávání. Jeho význam mưže být zastíněn typem studia (obsahem a cíli vzdělávání) a složením žáků v jednotlivých programech, nebot' programy se $v$ těchto ohledech značně liší.

Je ovšem možné, že akademický optimismus bezprostředně nepưsobí na vědomosti a dovednosti žáků v matematice a ve čtenářské gramotnosti, ale ovlivňuje nějaké jiné aspekty, např́klad výše zmiňovaný pocit sounáležitosti se školou. $Z$ toho důvodu se nám jeví užitečné zkoumat vliv akademického optimismu učitelů na nekognitivní výsledky vzdělávání. Do budoucna by bylo rovněž užitečné se zaměřit na to, zda neovlivňuje nějaké další charakteristiky školy, které působí na výsledky žáků, a má tedy na tyto výsledky zprostředkovaný vliv. Řada výzkumů, které cílily na další dimenze školního klimatu, takové vztahy prokázala. Jedním z potenciálních kandidátů je přístup vedení školy. V souvislosti s inkluzivní reformou je zajímavé zjištění, že existuje vztah mezi akademickým optimismem učitelů a sociálně spravedlivým leadershipem (Feng \& Chen, 2019). V centru pozornosti sociálně spravedlivého leadershipu je zajistit, aby přístup k znevýhodněným žákům umožňoval kompenzovat jejich znevýhodnění (Theoharis, 2007). Na základě svého výzkumu Feng a Chen (2019) usuzují, že když vedení školy dává najevo své přesvědčení, že 
je důležité poskytovat znevýhodněným žákům péči, která jim znevýhodnění umožní překonávat, může to zvyšovat přesvědčení učitelů, že i znevýhodnění žáci mohou dosáhnout dobrých výsledků.

Zajímavé jsou rozdíly v modelu vysvětlujícím výsledky v testu čtenářské gramotnosti a $v$ testu matematických vědomostí a dovedností na úrovni školy. Zatímco čtenářská gramotnost je dominantně ovlivněna socioekonomickým složením žáků školy, pro matematické vědomosti a dovednosti hraje stejnou roli primárně typ studia. Tento rozdíl přičítáme skutečnosti, že matematické kurikulum gymnaziálního a odborného studia se výrazně liší a matematické vědomosti a dovednosti jsou významně ovlivňovány školou. 0 rozvoj čtenářské gramotnosti škola pečuje méně cíleně, $k$ jejímu rozvoji pravděpodobně dochází spíše zprostředkovaně ve volném čase a v rodinách a zde se významně projevuje socioekonomické (a tedy velmi pravděpodobně i kulturní) složení žáků školy.

Je ovšem také možné, že výpověd' naší analýzy je negativně omezena typy vzdělávacích výsledků, které jsme zvolili. Matematické vědomosti a dovednosti tak, jak byly operacionalizovány ve výzkumu CLoSE, snad tvoří v kontextu středoškolského studia jako celku príliš specifickou oblast a bylo by vhodnější se zaměřit spíše na matematickou gramotnost. Naše studie má i některé další limity. Za nejvýznamnější limit považujeme, že jsme nebyli schopni v naší analýze rozlišovat mezi nematuritními a maturitními obory. Domníváme se, že prístup učitelů $\mathrm{k}$ žákům těchto oborů se liší, a tyto odlišnosti považujeme za důležité. Ochota učitelů vypovídat o př́stupu $k$ žákům a $k$ učitelské profesi je nicméně velmi omezená a nebylo $v$ našich silách zajistit $v$ jednotlivých odborných školách dostatečný počet výpovědí vztahujících se k oběma typům programů. I když jsme žádali ředitele o distribuci dotazníků učitelům, kteří dominantně učí (a v předchozích třech letech učili) $v$ testovaných třídách, učitelé nebyli přrirazeni $\mathrm{k}$ jednotlivým třídám a nevypovídali specificky o těchto třídách. Určité omezení lze spatřovat také $v$ tom, že učitelé byli dotazováni ve 3 . ročníku, nikoli $v 1$. ročníku studia žáků. Vycházíme nicméně $z$ toho, že postoje učitelů ve školách jsou relativně stabilní a v průběhu dvou let neprošly zásadní změnou.

\section{Poděkování}

Text je výstupem řešení projektu GA ČR Faktory ovlivňující kognitivní a nekognitivní výsledky žáků ve středním odborném vzdělávání. Úloha pocitu akademické marnosti a kultury školy (18-19056S).

\section{Literatura}

Aldridge, J. M., \& Fraser, B. J. (2015). Teachers' views of their school climate and its relationship with teacher self-efficacy and job satisfaction. Learning Environments Research, 19(2), 291-307. http://doi.org/10.1007/s10984-015-9198-x 
90 Anwar, M., \& Anis-ul-Haque, M. (2014). Teacher academic optimism: A preliminary study measuring the latent construct. FWU Journal of Social Sciences, 8(1), 10-16.

Bevel, R. K., \& Mitchell, R. M. (2012). The effects of academic optimism on elementary reading achievement. Journal of Educational Administration, 50(6), 773-787. http://doi. org/10.1108/09578231211264685

Boonen, T., Pinxten, M., Van Damme, J., \& Onghena, P. (2014). Should schools be optimistic? An investigation of the association between academic optimism of schools and student achievement in primary education. Educational Research and Evaluation, 20(1), 3-24. http: / / doi.org/10.1080/13803611.2013.860037

Brand, S., Felner, R. D., Seitsinger, A., Burns, A., \& Bolton, N. (2008). A large-scale study of the assessment of the social environment of middle and secondary schools: The validity and utility of teachers' ratings of school climate, cultural pluralism, and safety problems for understanding school effects and school improvement. Journal of School Psychology, 46(5), 507-535. http://doi.org/10.1016/j.jsp.2007.12.001

Brookover, W. B., Schweitzer, J. H., Schneider, J. M., Beady, Ch. H., Flood, P. K., \& Wisenbaker, J. M. (1978). Elementary school social climate and school achievement. American Educational Research Journal, 15(2), 301-318.

Byrne, B. M. (1998). Structural equation modeling with LISREL, PRELIS, and SIMPLIS: basic concepts, applications, and programming. Mahwah: Lawrence Erlbaum Associates. https:// doi.org/10.4324/9780203774762

Coleman, J. S., Campbell, E. Q., Hobson, C. J., McPartland, J., Mood, A. M., Weinfeld, F. D., \& York, R. L. (1966). Equality of educational opportunity. Washington: National Center for Education Statistics.

Collie, R. J., Shapka, J. D. , \& Perry, N. E. (2012). School climate and social-emotional learning: Predicting teacher stress, job satisfaction, and teaching efficacy. Journal of Educational Psychology, 104(4), 1189-1204. http://doi.org/10.1037/a0029356

Eren, A. (2014). Uncovering the links between prospective teachers' personal responsibility, academic optimism, hope, and emotions about teaching: A mediation analysis. Social Psychology of Education, 17(1), 73-104. http://doi.org/10.1007/s11218-013-9243-5

Fahy, P. F., Wu, H. C., \& Hoy, W. K. (2010). Individual academic optimism of teachers: A new concept and its measure. In W. K. Hoy \& M. F. DiPaola (Eds.), Analyzing school contexts: Influences of principals and teachers in the service of students (s. 209-227). Charlotte: Information Age.

Feng, F., \& Chen, W. (2019). The effect of principals' social justice leadership on teachers' academic optimism in Taiwan. Education and Urban Society, 51(9), 1245-1264. http: //doi. org/10.1177/0013124518785438

Gray, Ch., Wilcox, G., \& Nordstokke, D. (2017). Teacher mental health, school climate, inclusive education and student learning: A review. Canadian Psychology, 58(3), 203-210. http: //doi.org/10.1037/cap0000117

Grayson, J. L., \& Alvarez, H. K. (2008). School climate factors relating to teacher burnout: A mediator model. Teaching and Teacher Education, 24(5), 1349-1363. http://doi. org/10.1016/j.tate.2007.06.005

Hoy, W. K., Tarter, C. J., \& Woolfolk Hoy, A. (2006). Academic optimism of schools: A force for student achievement. American Educational Research Journal, 43(3), 425-446 http://doi. org/10.3102/00028312043003425

Hu, L., \& Bentler, P. M. (1999). Cutoff criteria for fit indexes in covariance structure analysis: Conventional criteria versus new alternatives. Structural Equation Modelling: A Multidisciplinary Journal, 6(1), 1-55. http://doi.org/10.1080/10705519909540118

Chang, I. (2011). A study of the relationships between distributed leadership, teacher academic optimism and student achievement in Taiwanese elementary schools. School Leadership \& Management, 31(5), 491-515. http://doi.org/10.1080/13632434.2011.614945

Ježek, S. (2003). Možnosti konceptualizace školního klimatu školy. In S. Ježek (Ed.), Psychosociální klima školy I (s. 2-31). Brno: MSD. 
Kirby, M. M., DiPaola, M. F. (2011). Academic optimism and community engagement in urban schools. Journal of Educational Administration, 49(5), 542-562 http://doi. org/10.1108/09578231111159539

Kösterelioğlu, M. A. (2017). The effect of teachers' shared leadership perception on academic optimism and organizational citizenship behaviour: A Turkish case. International Journal of Leadership in Education, 20(2), 246-258. http: / / doi.org/10.1080/13603124.2015.1066868

Maas, C. J. J., Hox, J. J. (2005). Sufficient sample sizes for multilevel modelling. Methodology European Journal of Research Methods for the Behavioral and Social Sciences, 1(3), 86-92.

Malinen, O., \& Savolainen, H. (2016). The effect of perceived school climate and teacher efficacy in behavior management on job satisfaction and burnout: A longitudinal study. Teaching and Teacher Education, 60, 144-152. http://doi.org/10.1016/j.tate.2016.08.012

Mareš, J. (2004). Přehled kvantitativních metod pro diagnostiku psychosociálního klimatu školy. In S. Ježek (Ed.), Psychosociální klima školy II (s. 87-114). Brno: MSD.

Martin, M. O., Foy, P., Mullis, I. V. S., \& O’Dwyer, L. M. (2013). Effective schools in reading, mathematics, and science at the fourth grade. In M. O. Martin \& I. V. S. Mullis (Eds.), TIMSS and PIRLS 2011. Relationships among reading, mathematics, and science achievement at the fourth grade-implications for early learning (s. 109-180). Chestnut Hill: TIMSS \& PIRLS International Study Center, Boston College.

Mascall, B., Leithwood, K., Straus, T., \& Sacks, R. (2008). The relationship between distributed leadership and teachers' academic optimism. Journal of Educational Administration, 46(2), 214-228.

McGuigan, L., \& Hoy, W. K. (2006). Principal leadership: Creating a culture of academic optimism to improve achievement for all students. Leadership \& Policy in Schools, 5(3), 203-229.

Meristo, M., \& Eisenschmidt, E. (2014). Novice teachers' perceptions of school climate and self-efficacy. International Journal of Educational Research, 67, 1-10. http://doi. org/10.1016/j.ijer.2014.04.003

Moghari, E., Lavasani, M. G., Bagherian, V., \& Afshari, J. (2011). Relationship between perceived teacher's academic optimism and English achievement: Role of self-efficacy. Procedia: Social \& Behavioral Sciences, 15, 2329-2333. http: / / doi.org/10.1016/j.sbspro.2011.04.102

Ngidi, D. (2012). Academic optimism: An individual teacher belief. Educational Studies, 38(2), 139-150. http://doi.org/10.1080/03055698.2011.567830

Ramelow, D., Currie, D., \& Felder-Puig, R. (2015). The assessment of school climate: Review and appraisal of published student-report measures. Journal of Psychoeducational Assessment, 33(8), 731-743. http://doi.org/10.1177/0734282915584852

Rudasill, K. M., Snyder, K. E., Levinson, H., \& Adelson, J. L. (2018). Systems view of school climate: A theoretical framework for research. Educational Psychology Review, 30(1), 35-60. http: //doi.org/10.1007/s10648-017-9401-y

Russell, S. L., Wentzel, K. R., \& Donlan, A. E. (2016). Teachers' beliefs about the development of teacher-adolescent trust. Learning Environments Research, 19(2), 241-266. http://doi. org/10.1007/s10984-016-9207-8

Sezgin, F., \& Erdogan, O. (2015). Academic optimism, hope and zest for work as predictors of teacher self-efficacy and perceived success. Educational Sciences: Theory \& Practice, 15(1), 7-19. http://doi.org/10.12738/estp.2015.1.2338

Smith, P. A., \& Hoy, W. K. (2007). Academic optimism and student achievement in urban elementary schools. Journal of Educational Administration, 45(5), 556-568. http://doi. org/10.1108/09578230710778196

Straková, J., Simonová, J., \& Greger, D. (2017). Ověření konceptu akademického optimismu na českých školách druhého stupně povinného vzdělávání. Pedagogická orientace, 27(3), 379-418.

Straková, J., Simonová, J., \& Greger, D. (2018). Vliv postojů učitelů na výsledky žáků. Sociologický časopis / Czech Sociological Review, 54(5), 727-748.

Theoharis, G. (2007). Social justice educational leaders and resistance: Toward a theory of social justice leadership. Educational Administration Quarterly, 43(2), 221-258. 
92 Van Houtte, M. \& Van Maele, D. (2012). Students' sense of belonging in technical/vocational schools versus academic schools: The mediating role of faculty trust in students. Teachers College Record, 114(7), 1-36.

Van Maele, D., \& Van Houtte, M. (2011). The quality of school life: Teacher-student trust relationships and the organizational school context. Social Indicators Research, 100(1), 85-100. http://doi.org/10.1007/s11205-010-9605-8

Wagner, C. A., \& DiPaola, M. F. (2011). Academic optimism of high school teachers: Its relationship to organizational citizenship behaviors and student achievement. Journal of School Leadership, 21(6), 893-926. http://doi.org/10.1177/105268461102100607

Wang, M., \& Degol, J. L. (2016). School climate: A review of the construct, measurement, and impact on student outcomes. Educational Psychology Review, 28(2), 315-352. http://doi. org/10.1007/s10648-015-9319-1

Woolfolk Hoy, A., Hoy, W. K., Kurz, N. M. (2008). Teacher's academic optimism: The development and test of a new construct. Teaching and Teacher Education, 24(4), 821-835 http: // doi.org/10.1016/j.tate.2007.08.004

Wu, J. H. (2013). Academic optimism and collective responsibility: An organizational model of the dynamics of student achievement. Asia Pacific Education Review, 14(3), 419-433. http: / /doi.org/10.1007/s12564-013-9269-6

Wu, J. H., Hoy, W. K., \& Tarter, C. J. (2013). Enabling school structure, collective responsibility, and a culture of academic optimism: Toward a robust model of school performance in Taiwan. Journal of Educational Administration, 51(2), 176-193. http://doi. org/10.1108/09578231311304698

Korespondenční autorka: doc. RNDr. Jana Straková, Ph.D. Ústav výzkumu a rozvoje vzdělávání

Pedagogická fakulta Univerzita Karlova Myslíkova 7 11000 Praha 1 jana.strakova@pedf.cuni.cz 